Article

\title{
Bio-Hydrogen Production from Pineapple Waste Extract by Anaerobic Mixed Cultures
}

Alissara Reungsang ${ }^{1,2, *}$ and Chakkrit Sreela-or ${ }^{3}$

1 Department of Biotechnology, Faculty of Technology, Khon Kaen University, Khon Kaen 40002, Thailand

2 Research Group for Development of Microbial Hydrogen Production Process from Biomass, Khon Kaen University, Khon Kaen 40002, Thailand

3 Department of Agriculture, Faculty of Food and Agricultural Technology, Phibulsongkram Rajabhat University, Phitsanulok 65000, Thailand; E-Mail: madeaw370@gmail.com

* Author to whom correspondence should be addressed; E-Mail: alissara@kku.ac.th;

Tel./Fax: +66-43-362-121.

Received: 27 December 2012; in revised form: 7 March 2013 / Accepted: 2 April 2013 /

Published: 18 April 2013

\begin{abstract}
A statistical experimental design was employed to optimize factors that affect the production of hydrogen from the glucose contained in pineapple waste extract by anaerobic mixed cultures. Results from Plackett-Burman design indicated that substrate concentration, initial $\mathrm{pH}$ and $\mathrm{FeSO}_{4}$ concentration had a statistically significant $(p \leq 0.05)$ influence on the hydrogen production potential $\left(P_{S}\right)$ and the specific hydrogen production rate (SHPR). The path of steepest ascent was undertaken to approach the optimal region of these three significant factors which was then optimized using response surface methodology (RSM) with central composite design (CCD). The presence of a substrate concentration of 25.76 g-total sugar/L, initial $\mathrm{pH}$ of 5.56 , and $\mathrm{FeSO}_{4}$ concentration of $0.81 \mathrm{~g} / \mathrm{L}$ gave a maximum predicted $P_{s}$ of $5489 \mathrm{~mL} \mathrm{H}_{2} / \mathrm{L}$, hydrogen yield of $1.83 \mathrm{~mol} \mathrm{H}_{2} / \mathrm{mol}$ glucose, and SHPR of $77.31 \mathrm{~mL} \mathrm{H}_{2} /$ g-volatile suspended solid (VSS) h. A verification experiment indicated highly reproducible results with the observed $P_{s}$ and SHPR being only $1.13 \%$ and $1.14 \%$ different from the predicted values.
\end{abstract}

Keywords: pineapple waste extract; bio-hydrogen 


\section{Introduction}

Hydrogen is a promising alternative energy carrier and is also considered to be a clean energy. It only produces water when combusted with oxygen and has an energy content 2.75 times higher than hydrocarbon fuels [1,2]. Hydrogen can be produced using biological, chemical, and physical processes. The biological hydrogen production process has gained more interest than chemical and physical processes because it is a sustainable process that consumes less energy. Biological hydrogen production can be divided into two types, i.e., a phototrophic process and a dark fermentation process. Dark fermentation has advantages over the phototrophic process in terms of its ability to continuously produce hydrogen from a variety of feedstocks without an external input of energy [3].

Pineapple waste is basically composed of residual pulp, peel, and cores. Pineapple waste is not considered attractive as an animal feed because of its high fiber content, high soluble carbohydrate and low protein content [4]. However, the pineapple waste extract, i.e., the juice obtained after the pineapple waste has been squeezed by a presser, mainly contains sugars and organic acids that can be utilized as the substrates in the production of hydrogen and ethanol [5-8]. Due to its composition, we attempted to use the pineapple waste extract in hydrogen production using anaerobic mixed cultures. In order to achieve maximum hydrogen production, there was a need to provide suitable fermentation conditions, especially the environmental factors such as temperature, $\mathrm{pH}$, nutrient addition, buffer, substrate concentration and ferrous iron. The appropriate concentration of substrate could enhance bacterial growth and activity [9]. An excessive substrate concentration can cause a build-up of volatile fatty acid (VFAs) in the fermentation broth, leading to a low $\mathrm{pH}$ in the system. Moreover, pineapple waste extract contains a high amount of short chain organic acids, which in turn means that the extract would have a low $\mathrm{pH}$ and a high acid concentration. A high acidic content in the substrate can cause adverse effects on hydrogen production. Thus, the addition of a buffer to counteract a decrease in $\mathrm{pH}$ is needed. Endo-nutrient and iron are often used to enrich microorganisms capable of producing hydrogen. The important elements contained in the Endo-nutrient such as $\mathrm{Cu}^{2+}, \mathrm{Co}^{2+}, \mathrm{Mg}^{2+}$ are essential for microorganism growth and activity. Iron is the important element for the activity of hydrogenase, which is an important enzyme for hydrogen production [10,11]. Initial $\mathrm{pH}$ is a physical factor that also has a great influence on hydrogen production. In general, the appropriate range of initial $\mathrm{pH}$ for hydrogen production and cell growth is in the ranges of 4.0-7.0 [10,11]. If the initial $\mathrm{pH}$ is outside the optimal range, and if enough buffer capacity is not present, the hydrogen production process will be inhibited [10,11].

Accordingly, the goal of this research was to optimize the environmental key factors that influence the biohydrogen production from pineapple waste extract by anaerobic mixed cultures. A Plackett-Burmann design was used to screen the significant variables. Response surface methodology (RSM) with central composite design (CCD) was used to optimize the levels of these variables. The results were expected to provide the optimal conditions for improving and enhancing the hydrogen production potential from pineapple waste extract. 


\section{Results and Discussion}

\subsection{Screening of the Significant Variables Affecting Hydrogen Production from Pineapple Waste Extract by Anaerobic Mixed Cultures}

The key factors that affected hydrogen production from pineapple waste extract were screened using the Plackett-Burman design. Table 1 shows the significance and effects of each variable on hydrogen production potential $\left(P_{S}\right)$ and specific hydrogen production rate (SHPR). The effect of each variable was calculated by the difference between the averages of measurements made at the high and low level of the factor.

The sign of the effect value $\left(E x_{i}\right)$ showed the influence of the variable on $P_{s}$ and SHPR. The negative sign of the effect showed that the influence of a variable on the response should be lower than that of the low level $(-1)$, whereas the positive sign of the effect showed that the influence of the variable on response should be higher than that of the high level $(+1)$. The results indicated that the influence of $\mathrm{FeSO}_{4}$ concentration, initial $\mathrm{pH}$, and $\mathrm{NaHCO}_{3}$ concentration were greater at a low level while the influence of Endo-nutrient and substrate concentration were greater at a high level (Table 1). The significance of each variable was determined by the probability value. Results indicated that $\mathrm{FeSO}_{4}$ concentration, initial $\mathrm{pH}$, and substrate concentration had a significant effect on $P_{s}$ and SHPR $(p \leq 0.05)$. Therefore, these three variables were chosen for the next optimization step.

Table 1. Levels of the variables and statistical analysis in Plackett-Burman design for $P_{s}$ and SHPR.

\begin{tabular}{|c|c|c|c|c|c|c|c|c|c|}
\hline \multirow{2}{*}{ Code } & \multirow{2}{*}{ Variable } & \multirow{2}{*}{$\begin{array}{l}\text { Low } \\
\text { level }\end{array}$} & \multirow{2}{*}{$\begin{array}{l}\text { High } \\
\text { level }\end{array}$} & \multicolumn{3}{|c|}{$P_{s}(\mathrm{~mL} \mathrm{H} / \mathrm{L})$} & \multicolumn{3}{|c|}{$\begin{array}{l}\text { SHPR [mL } \mathrm{H}_{2} / \text { g-volatile } \\
\text { suspended solid (VSS) h] }\end{array}$} \\
\hline & & & & $\begin{array}{c}\text { Effect } \\
\left(E x_{i}\right)\end{array}$ & $F$-Values & $\begin{array}{l}p \text {-Value } \\
\text { Prob }>F\end{array}$ & $\begin{array}{c}\text { Effect } \\
\left(E x_{i}\right)\end{array}$ & $F$-Values & $\begin{array}{l}p \text {-Value } \\
\text { Prob }>F\end{array}$ \\
\hline$X_{1}$ & $\mathrm{FeSO}_{4}$ concentration $(\mathrm{g} / \mathrm{L})$ & 1 & 2 & -549.00 & 13.38 & 0.0106 & -7.73 & 13.38 & 0.0018 \\
\hline$X_{2}$ & Initial pH & 5 & 7 & -1189.19 & 62.77 & 0.0002 & -16.74 & 62.77 & 0.0002 \\
\hline$X_{3}$ & Endo-nutrient $(\mathrm{mL} / \mathrm{L})$ & 0.5 & 2 & 2.36 & 0.002 & 0.9879 & 0.03 & 0.002 & 0.9879 \\
\hline$X_{4}$ & $\begin{array}{l}\text { Substrate concentration } \\
\quad(\mathrm{g} \text {-total sugar } / \mathrm{L})\end{array}$ & 10 & 20 & 421.1 & 7.87 & 0.0309 & 5.93 & 7.87 & 0.0309 \\
\hline$X_{5}$ & $\mathrm{NaHCO}_{3}$ concentration $(\mathrm{g} / \mathrm{L})$ & 1 & 5 & -97.01 & 0.42 & 0.542 & -1.37 & 0.42 & 0.542 \\
\hline
\end{tabular}

\subsection{The Path of Steepest Ascent}

The path of steepest ascent was used in order to approach the proper direction of the changing variable. Results indicated that an increase in substrate concentration from 20 to 25 g-total sugar/L resulted in an increase in $P_{s}$ and SHPR by $22.74 \%$ and $22.71 \%$ (Table 2), respectively. An increase in substrate concentration greater than $25 \mathrm{~g}$-total sugar/L caused a decrease in $P_{s}$ and SHPR by $13.18 \%$ and $13.16 \%$, respectively. Based on these results, the selected range of substrate concentration of 20-30 g-total sugar/L was used in the optimization step through RSM with CCD.

$P_{s}$ and SHPR were increased with a decrease in initial $\mathrm{pH}$ from 6.0 to 5.5. A further decrease in the initial $\mathrm{pH}$ to less than 5.5 resulted in a decrease in $P_{s}$ and SHPR (Table 2). The highest $P_{s}$ and SHPR of $4680 \mathrm{~mL} \mathrm{H} / \mathrm{L}$ and $65.87 \mathrm{~mL} \mathrm{H}_{2} / \mathrm{g}$-VSS h, respectively, were achieved at the initial $\mathrm{pH}$ of 5.5. 
Therefore the selected range of initial $\mathrm{pH}$ used in the optimization experiment was chosen to be between 6.0 and $5.0 \mathrm{~g} / \mathrm{L}$.

The effect of $\mathrm{FeSO}_{4}$ concentration on $P_{s}$ and SHPR was also investigated. The highest $P_{s}$ and SHPR of $4680 \mathrm{~mL} \mathrm{H}_{2} / \mathrm{L}$ and $65.87 \mathrm{~mL} \mathrm{H}_{2} / \mathrm{g}-\mathrm{VSS} \mathrm{h}$ were obtained at $0.8 \mathrm{~g} / \mathrm{L} \mathrm{FeSO}_{4}$. Based on this result, the $\mathrm{FeSO}_{4}$ concentration that ranged between 1.0 to $0.6 \mathrm{~g} / \mathrm{L}$ was used in the optimization experiment. The results from the path of steepest ascent indicated that the selected ranges of substrate concentration, initial $\mathrm{pH}$ and $\mathrm{FeSO}_{4}$ concentration to be used in the optimization study were 20-30 g-total sugar/L, 6.0-5.0 $\mathrm{g} / \mathrm{L}$, and 1.0-0.6 g/L, respectively.

Table 2. Results and experimental design of the path of steepest ascent.

\begin{tabular}{|c|c|c|c|c|c|}
\hline Run & $\begin{array}{c}\text { Substrate concentration } \\
\quad(\text { g-total sugar } / \mathrm{L})\end{array}$ & Initial pH & $\begin{array}{c}\mathrm{FeSO}_{4} \text { concentration } \\
(\mathrm{g} / \mathrm{L})\end{array}$ & $\begin{array}{c}\boldsymbol{P}_{s} \\
\left(\mathrm{~mL} \mathrm{H} \mathrm{H}_{2} / \mathrm{L}\right)\end{array}$ & $\begin{array}{c}\text { SHPR } \\
(\mathrm{mL} \mathrm{H} / \mathrm{g}-\mathrm{VSS} \text { h) }\end{array}$ \\
\hline 1 & 20 & 6.0 & 1.0 & 3616 & 50.91 \\
\hline 2 & 25 & 5.5 & 0.8 & 4680 & 65.87 \\
\hline 3 & 30 & 5.0 & 0.6 & 4063 & 57.20 \\
\hline 4 & 35 & 4.5 & 0.4 & 3033 & 42.70 \\
\hline 5 & 40 & 4.0 & 0.2 & 2702 & 38.03 \\
\hline
\end{tabular}

2.3. Optimization of Substrate Concentration, Initial $\mathrm{pH}$, and $\mathrm{FeSO}_{4}$ Concentration on $P_{s}$ Using RSM with $C C D$

CCD was used to optimize substrate concentration, initial $\mathrm{pH}$, and $\mathrm{FeSO}_{4}$ concentration on $P_{s}$. Regression analysis of the data from Table 3 resulted in the quadratic equation [Equation (1)] as follows:

$$
\begin{aligned}
P s= & +5317.17+145.00 X_{1}+103.31 X_{2}+79.71 X_{3}-94.42 X_{1} X_{2}-119.46 X_{1} X_{3} \\
& +93.00 X_{2} X_{3}-413.53 X_{1}^{2}-430.37 X_{2}^{2}-541.86 X_{3}^{2}
\end{aligned}
$$

where $P_{s}$ is the hydrogen production potential; and $X_{1}, X_{2}$ and $X_{3}$ are the substrate concentration, initial $\mathrm{pH}$, and $\mathrm{FeSO}_{4}$ concentration, respectively. The model showed a high determination coefficient $\left(R^{2}=0.99\right)$, explaining $99 \%$ of the variability in the response. A very low probability $(p<0.0001)$ obtained from the regression analysis of variance (ANOVA) demonstrated that the model was significant (Table 4).

The significance of the variables was determined by the probability values (Table 4$)$. Results showed that substrate concentration $\left(X_{1}\right)$, initial $\mathrm{pH}\left(X_{2}\right)$, and $\mathrm{FeSO}_{4}$ concentration $\left(X_{3}\right)$ had a significant individual effect on $P_{s}(p \leq 0.05)$. The quadratic model terms of all variables $\left(X_{1}^{2}, X_{2}^{2}\right.$ and $\left.X_{3}^{2}\right)$ are highly significant $(p \leq 0.0001)$. A significant interaction effect on $P_{s}$ was found between substrate concentration and initial $\mathrm{pH}\left(X_{1} X_{2}\right)$, substrate concentration and $\mathrm{FeSO}_{4}$ concentration $\left(X_{1} X_{3}\right)$, and initial $\mathrm{pH}$ and $\mathrm{FeSO}_{4}$ concentration $\left(X_{2} X_{3}\right)(p \leq 0.05)$. Based on the regression analysis of the model [Equation (1)], the maximum $P_{s}$ of $5425 \mathrm{~mL} \mathrm{H}_{2} / \mathrm{L}$ could be predicted at the substrate concentration of 25 g-total sugar/L, initial $\mathrm{pH}$ of 5.56 and $\mathrm{FeSO}_{4}$ concentration of $0.78 \mathrm{~g} / \mathrm{L}$. The response surface plots based on Equation (1), with one variable kept constant at their optimum values and variations of the other two variables within the experimental range are depicted in Figure 1. Results indicated that the optimum conditions for maximum $P_{S}$ fell well inside the design boundaries. 
Table 3. Central composite experimental design matrix defining $\mathrm{pH}$, substrate concentration and $\mathrm{FeSO}_{4}$ concentration for optimizing the fermentative hydrogen production process and the corresponding experimental results.

\begin{tabular}{|c|c|c|c|c|c|c|c|c|c|c|}
\hline \multirow[t]{2}{*}{ Run } & \multicolumn{2}{|c|}{$\begin{array}{c}\text { Substrate } \\
\text { concentration }\left(X_{1}\right) \\
\text { (g-total sugar } / \mathrm{L})\end{array}$} & \multicolumn{2}{|c|}{ Initial pH $\left(X_{2}\right)$} & \multicolumn{2}{|c|}{$\begin{array}{c}\mathrm{FeSO}_{4} \text { concentration } \\
\qquad\left(X_{3}\right)(\mathrm{g} / \mathrm{L})\end{array}$} & \multicolumn{2}{|c|}{ 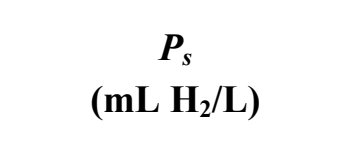 } & \multicolumn{2}{|c|}{$\begin{array}{c}\text { SHPR } \\
(\mathrm{mL} \mathrm{H} / \mathrm{g}-\mathrm{VSS} \mathrm{h})\end{array}$} \\
\hline & $\begin{array}{l}\text { Code } \\
\text { value }\end{array}$ & $\begin{array}{c}\text { Actual } \\
\text { value }\end{array}$ & $\begin{array}{l}\text { Code } \\
\text { value }\end{array}$ & $\begin{array}{c}\text { Actual } \\
\text { value }\end{array}$ & $\begin{array}{l}\text { Code } \\
\text { value }\end{array}$ & $\begin{array}{c}\text { Actual } \\
\text { value }\end{array}$ & Observed & Predicted & Observed & Predicted \\
\hline 1 & 0.00 & 25.00 & 0.00 & 5.50 & 0.00 & 0.80 & 5332 & 5317 & 75.05 & 74.85 \\
\hline 2 & 0.00 & 25.00 & 0.00 & 5.50 & 0.00 & 0.80 & 5306 & 5317 & 74.68 & 74.85 \\
\hline 3 & 1.00 & 30.00 & 1.00 & 6.00 & 1.00 & 1.00 & 4137 & 4139 & 58.23 & 58.21 \\
\hline 4 & -1.00 & 20.00 & -1.00 & 5.00 & 1.00 & 1.00 & 3875 & 3695 & 54.54 & 52.27 \\
\hline 5 & 0.00 & 25.00 & 0.00 & 5.50 & 0.00 & 0.80 & 5337 & 5317 & 75.13 & 74.85 \\
\hline 6 & 1.00 & 30.00 & -1.00 & 5.00 & -1.00 & 0.60 & 4237 & 4200 & 59.64 & 59.07 \\
\hline 7 & 1.68 & 33.41 & 0.00 & 5.50 & 0.00 & 0.80 & 4464 & 4391 & 62.84 & 61.79 \\
\hline 8 & -1.00 & 20.00 & -1.00 & 5.00 & -1.00 & 0.60 & 3562 & 3483 & 50.14 & 49.03 \\
\hline 9 & 0.00 & 25.00 & 0.00 & 5.50 & -1.68 & 0.46 & 3606 & 3651 & 50.76 & 51.36 \\
\hline 10 & 0.00 & 25.00 & -1.68 & 4.66 & 0.00 & 0.80 & 3815 & 3926 & 53.7 & 55.33 \\
\hline 11 & 0.00 & 25.00 & 0.00 & 5.50 & 1.68 & 1.14 & 3853 & 3919 & 54.24 & 55.24 \\
\hline 12 & 1.00 & 30.00 & 1.00 & 6.00 & -1.00 & 0.60 & 3957 & 4032 & 55.7 & 56.85 \\
\hline 13 & -1.00 & 20.00 & 1.00 & 6.00 & 1.00 & 1.00 & 4317 & 4276 & 60.77 & 60.21 \\
\hline 14 & 1.00 & 30.00 & -1.00 & 5.00 & 1.00 & 1.00 & 3916 & 3935 & 55.12 & 55.39 \\
\hline 15 & 0.00 & 25.00 & 0.00 & 5.50 & 0.00 & 0.80 & 5194 & 5317 & 73.12 & 74.85 \\
\hline 16 & -1.68 & 16.59 & 0.00 & 5.50 & 0.00 & 0.80 & 3721 & 3904 & 52.38 & 55.04 \\
\hline 17 & 0.00 & 25.00 & 0.00 & 5.50 & 0.00 & 0.80 & 5340 & 5317 & 75.17 & 74.85 \\
\hline 18 & -1.00 & 20.00 & 1.00 & 6.00 & -1.00 & 0.60 & 3789 & 3692 & 53.33 & 51.93 \\
\hline 19 & 0.00 & 25.00 & 1.68 & 6.34 & 0.00 & 0.80 & 4275 & 4274 & 60.18 & 60.14 \\
\hline 20 & 0.00 & 25.00 & 0.00 & 5.50 & 0.00 & 0.80 & 5413 & 5317 & 76.2 & 74.85 \\
\hline
\end{tabular}

Table 4. Model coefficients estimated by multiple linear regressions.

\begin{tabular}{ccccc}
\hline \multirow{2}{*}{ Factor } & \multicolumn{2}{c}{$\boldsymbol{P}_{\boldsymbol{s}}\left(\mathbf{m L ~ H}_{\mathbf{2}} / \mathbf{L}\right)$} & \multicolumn{2}{c}{ SHPR $\left(\mathbf{m L ~} \mathbf{H}_{\mathbf{2}} / \mathbf{g}\right.$-VSS h) } \\
\cline { 2 - 5 } & Coefficient estimate & Probability & Coefficient estimate & Probability \\
\hline Model & 5317.17 & $<0.0001$ & 74.85 & $<0.0001$ \\
$X_{1}$ & 145 & 0.0009 & 2.01 & 0.0012 \\
$X_{2}$ & 103.31 & 0.0076 & 1.43 & 0.0101 \\
$X_{3}$ & 79.71 & 0.0278 & 1.15 & 0.0286 \\
$X_{1} X_{2}$ & -94.42 & 0.0419 & -1.28 & 0.0543 \\
$X_{1} X_{3}$ & -119.46 & 0.0145 & -1.73 & 0.0148 \\
$X_{2} X_{3}$ & 93 & 0.0445 & 1.26 & 0.0576 \\
$X_{1}{ }^{2}$ & -413.53 & $<0.0001$ & -5.81 & $<0.0001$ \\
$X_{2}$ & -430.37 & $<0.0001$ & -6.05 & $<0.0001$ \\
$X_{3}{ }^{2}$ & -541.86 & $<0.0001$ & -7.62 & $<0.0001$ \\
\hline
\end{tabular}


Figure 1. Response surface plots showing (a) the effects of initial pH, substrate concentration, and their mutual interaction on $P_{s}$ with optimum level of $\mathrm{FeSO}_{4}$ concentration $(0.78 \mathrm{~g} / \mathrm{L})$; (b) the effects of $\mathrm{FeSO}_{4}$ concentration, substrate concentration and their mutual interaction on $P_{s}$ with optimum level of initial $\mathrm{pH}(5.56)$; and (c) the effects of $\mathrm{FeSO}_{4}$ concentration, initial $\mathrm{pH}$ and their mutual interaction on $P_{s}$ with optimum level of substrate concentration (25 g-total sugar/L).
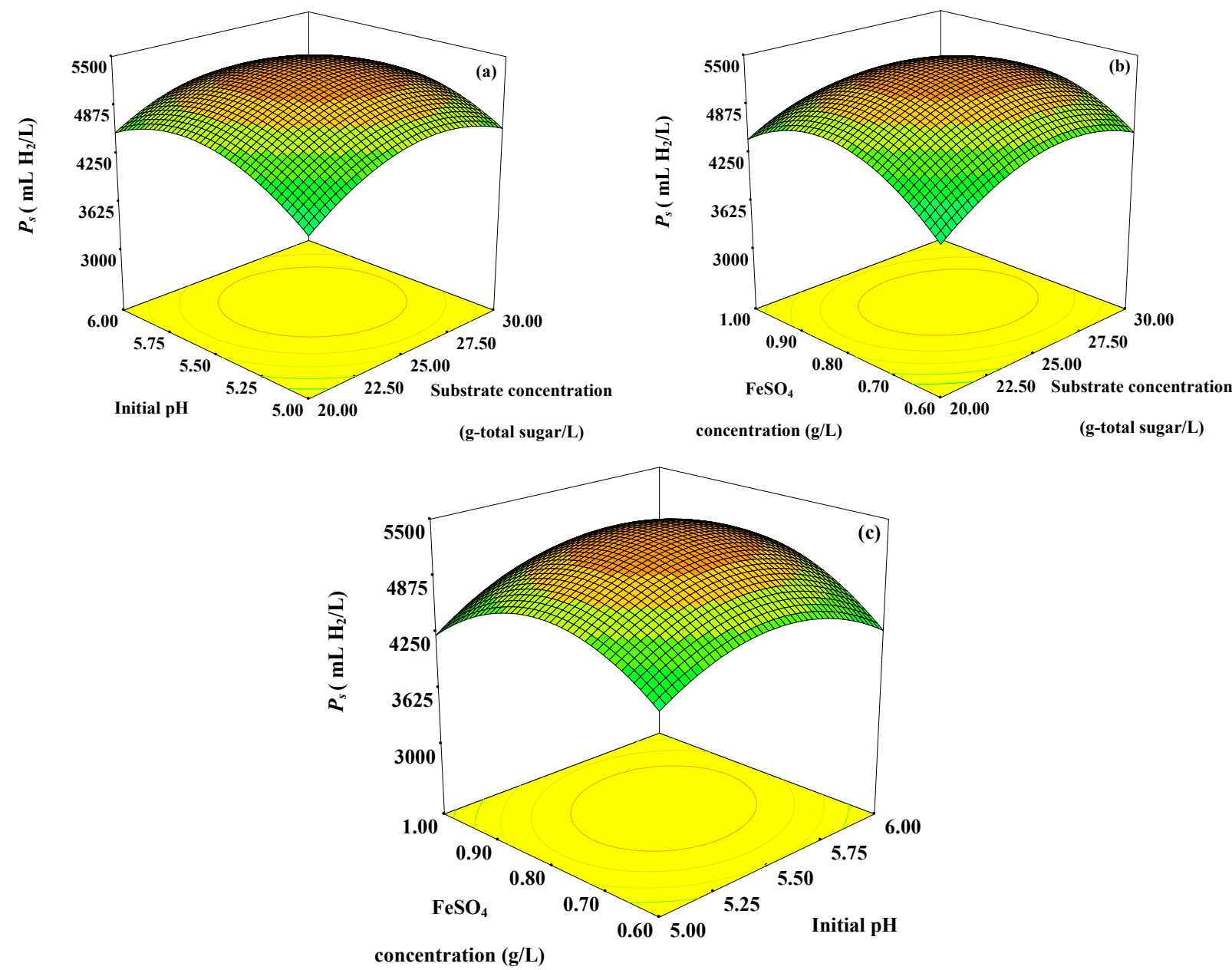

The $P_{s}$ increased with increasing substrate concentration up to 25 g-total sugar/L. Further increase in substrate concentration greater than $25 \mathrm{~g}$-total sugar/L resulted in lower $P_{s}$ (Figure 1a,b). This might be due to substrate and product (VFAs) inhibitions. A high substrate concentration, not exceeding the substrate inhibition level, in the fermentation broth resulted in a high $P_{s}$ because substrate was used to produce hydrogen. An increase in the substrate concentration higher than optimum level might develop osmotic pressure inside the microbial cells, which can cause cell damage due to the permeation of water molecules out of the cells [12]; hence a reduction of hydrogen production occurred. In addition, an increase in substrate concentration could have led to a partial pressure of hydrogen build-up in the fermentation system. When the partial pressure accumulates in the headspace of the serum bottle to a certain level, hydrogen production will be switched to solvent production, thus hydrogen production was inhibited [13]. Therefore, the substrate concentration should be optimized in order to prevent the shock loads of the system [14]. 
The $P_{s}$ increased when the initial $\mathrm{pH}$ increased from $\mathrm{pH} 5.00$ to 5.56. However, a further increase in initial $\mathrm{pH}$ to levels greater than $\mathrm{pH} 5.56$ resulted in a decrease in $P_{s}$ (Figure 1a,c). The initial $\mathrm{pH}$ is an important factor in hydrogen production because it affects metabolic pathways, iron (Fe)-hydrogenase activity and the duration of the lag phase [13-18]. When the initial $\mathrm{pH}$ was high, the metabolic pathway will have shifted from acidogenesis to solventogenesis [13-18]. The low initial $\mathrm{pH}$ value of $\mathrm{pH} 4.0-4.5$ was reported to cause a long lag period [13]. In contrast, a high initial $\mathrm{pH}$ value, for example $\mathrm{pH} 9.0$ could decrease the lag time but it would result in a low level of hydrogen production [13-19].

An increase in the $\mathrm{FeSO}_{4}$ concentration from 0.60 to $0.78 \mathrm{~g} / \mathrm{L}$ increased the $P_{s}$ (Figure 1a,c). However, the results indicated that $P_{s}$ was decreased when the $\mathrm{FeSO}_{4}$ concentration was greater than $0.78 \mathrm{~g} / \mathrm{L}$. Iron is needed in hydrogen production by anaerobic fermentation because it forms ferredoxin and hydrogenase, which is directly related to the hydrogen production process. Iron can affect the fermentative production of hydrogen by influencing the activity of hydrogenases [20-23]. The optimum iron concentration could enhance fermentative hydrogen production by mixed cultures, while lower or higher iron concentrations than optimum range could reduce the activity of hydrogenases [20-23].

\subsection{Optimization of Substrate Concentration, Initial $\mathrm{pH}$, and $\mathrm{FeSO}_{4}$ Concentration on SHPR Using RSM with CCD}

Optimization of substrate concentration, initial $\mathrm{pH}$, and $\mathrm{FeSO}_{4}$ concentration on SHPR was conducted using RSM with CCD. The observed and predicted values of SHPR are presented in Table 3. Multiple regression analysis was applied to the data in Table 3 and the second-order polynomial equation [Equation (2)] obtained could well explain the SHPR values:

$$
\begin{aligned}
S H P R= & +74.85+2.01 X_{1}+1.43 X_{2}+1.15 X_{3}-1.28 X_{1} X_{2}-1.73 X_{1} X_{3} \\
& -1.26 X_{2} X_{3}-5.81 X_{1}^{2}-6.05 X_{2}^{2}-7.62 X_{3}^{2}
\end{aligned}
$$

where SHPR is the specific hydrogen production rate and $X_{1}, X_{2}$ and $X_{3}$ are the codes of substrate concentration, initial $\mathrm{pH}$, and $\mathrm{FeSO}_{4}$ concentration, respectively. The quadratic regression model indicated that the model was significant with a low probability $(p<0.0001)$. All variables, i.e., substrate concentration, initial $\mathrm{pH}$, and $\mathrm{FeSO}_{4}$ concentration showed probability values of less than 0.05, which indicated their significant individual effect on SHPR (Table 4). The quadratic model terms of all variables $\left(X_{1}^{2}, X_{2}^{2}\right.$ and $\left.X_{3}^{2}\right)$ are highly significant $(p \leq 0.0001)$. A significant interactive effect on SHPR was found between substrate concentration and $\mathrm{FeSO}_{4}$ concentration $\left(X_{1} X_{3}\right)$ (Table 4). Based on the regression analysis of the model [Equation (2)], the maximum SHPR of $75.27 \mathrm{~mL} \mathrm{H}_{2} / \mathrm{g}$-VSS $\mathrm{h}$ could be predicted at the substrate concentration of 25.06 g-total sugar/L, initial $\mathrm{pH}$ of 5.50 and $\mathrm{FeSO}_{4}$ concentration of $0.81 \mathrm{~g} / \mathrm{L}$.

The response surface plots based on Equation (2), with one variable kept constant at their optimum values and variations of the other two variables within the experimental range, are depicted in Figure 2. SHPR increased when the substrate concentration increased from 20 to 25 g-total sugar/L and then SHPR slightly decreased with a further increase in substrate concentration (Figure 2a,b). The substrate limitation and substrate inhibition effects might be responsible for our findings [19,24,25]. Within the appropriate range, an increase in substrate concentration could improve the ability of hydrogen producing bacteria to produce hydrogen during the fermentation process [19,24,25]. However, a high 
substrate concentration could result in a high concentration of the short chain organic acid contained in pineapple waste extract and a low $\mathrm{pH}$ of the fermentation broth, which might be toxic to the growth of hydrogen producing bacteria.

Figure 2. Response surface plots showing: (a) the effects of initial $\mathrm{pH}$, substrate concentration, and their mutual interaction on SHPR with optimum level of $\mathrm{FeSO}_{4}$ concentration $(0.81 \mathrm{~g} / \mathrm{L})$; (b) the effects of $\mathrm{FeSO}_{4}$ concentration, substrate concentration and their mutual interaction on SHPR with optimum level of initial $\mathrm{pH}$ (5.50); and (c) the effects of $\mathrm{FeSO}_{4}$ concentration, initial $\mathrm{pH}$ and their mutual interaction on SHPR with optimum level of substrate concentration (25.06 g-total sugar/L).
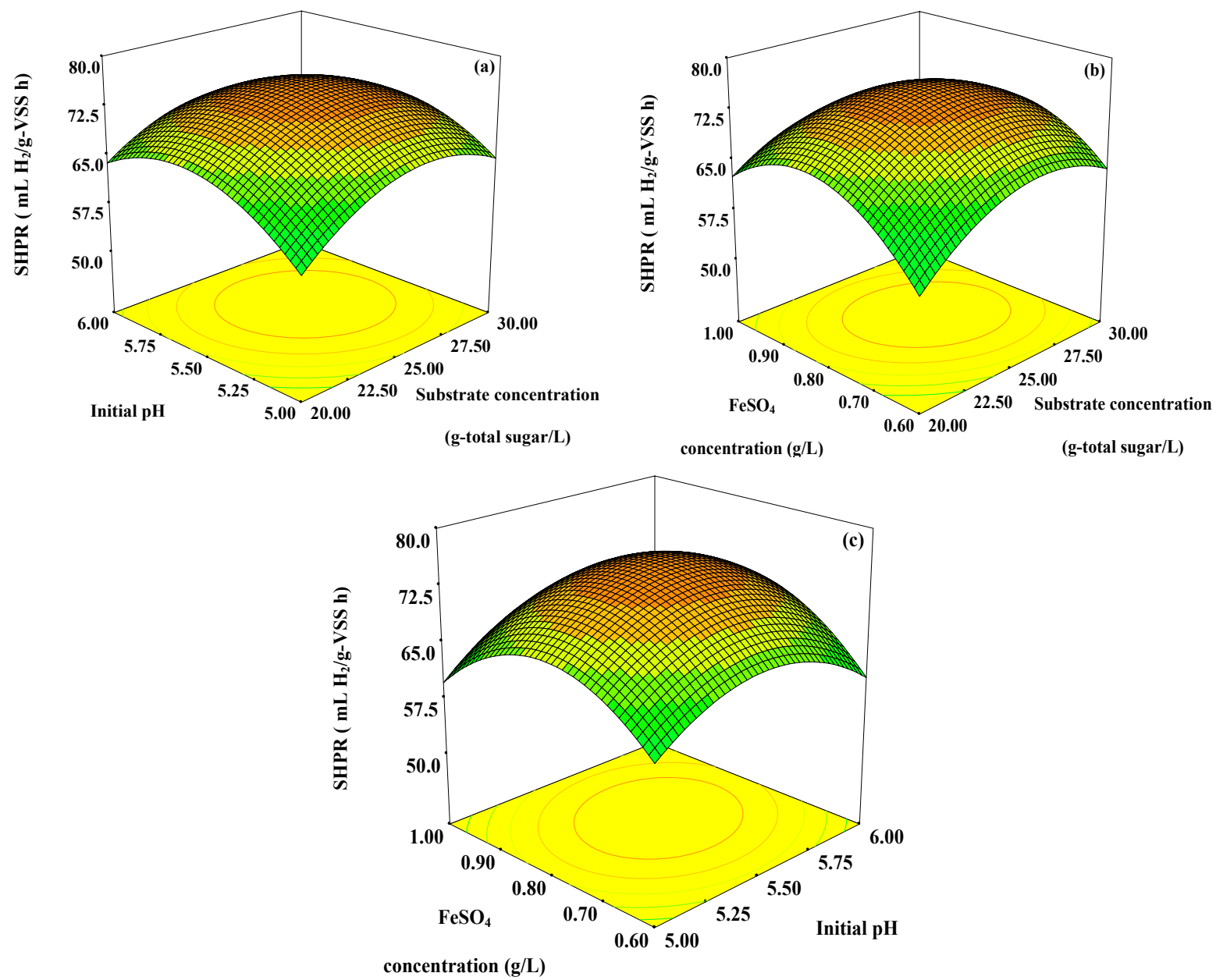

SHPR increased with an increase in initial $\mathrm{pH}$ from 5.00 to 5.50 and decreased with an increase in initial pH greater than 5.50 (Figure 2a,c). Thus, a high initial pH causes low SHPR due to the activity of hydrogenase enzyme being inhibited at a strong basidic condition [15,17]. Our results showed that a suitable initial $\mathrm{pH}$ is important to maximize hydrogen production from pineapple waste extract. However, the appropriate range of initial $\mathrm{pH}$ for hydrogen production and microbial growth is varied according to the cultivation conditions, such as the inocula used, substrate concentration, and incubation temperature $[18,19]$. 
SHPR rapidly increased when the $\mathrm{FeSO}_{4}$ concentration was increased up to $0.81 \mathrm{~g} / \mathrm{L}$, then the SHPR gradually decreased when the $\mathrm{FeSO}_{4}$ concentration was higher than $0.81 \mathrm{~g} / \mathrm{L}$ (Figure $2 \mathrm{~b}, \mathrm{c}$ ). Iron is an important factor affecting hydrogen production as previously described in the introduction. Thus in the optimal range, an increase in iron concentration not exceeding the optimum level could enhance the SHPR from pineapple waste extract.

\subsection{Confirmation Experiment}

The analysis of the $P_{s}$ and SHPR [Equations (1) and (2)] model suggested that in order to obtain the maximum $P_{S}$ and SHPR, substrate concentration, initial $\mathrm{pH}$, and $\mathrm{FeSO}_{4}$ concentration should be optimized at 25.76 g-total sugar/L, 5.56 and $0.81 \mathrm{~g} / \mathrm{L}$, respectively (Table 5). A $P_{s}$ and SHPR of $5489 \mathrm{~mL} \mathrm{H}_{2} / \mathrm{L}$ and $77.31 \mathrm{~mL} \mathrm{H}_{2} / \mathrm{g}$-VSS $\mathrm{h}$ were predicted under the optimum conditions.

In order to confirm the validity of the statistics based experimental strategy, three replicates of each batch experiment were performed under the optimum conditions. The $P_{s}$ and SHPR results indicated that the observed $P_{S}$ and SHPR ( $5427 \mathrm{~mL} \mathrm{H}_{2} / \mathrm{L}$ and $76.43 \mathrm{~mL} \mathrm{H}_{2} / \mathrm{g}$-VSS h) are in close agreement with the predicted values of $P_{s}$ and SHPR with only $1.13 \%$ and $1.14 \%$ differences. Results suggested that the model obtained from the CCD experiment is valid.

Table 5. Results and experimental design of confirmation test.

\begin{tabular}{|c|c|c|c|c|c|c|}
\hline Condition & $\begin{array}{c}\text { Substrate } \\
\text { concentration } \\
\text { (g-total sugar } / \mathbf{L})\end{array}$ & $\begin{array}{c}\text { Initial } \\
\text { pH }\end{array}$ & $\begin{array}{c}\mathrm{FeSO}_{4} \\
\text { concentration } \\
(\mathrm{g} / \mathrm{L}) \\
\end{array}$ & $\begin{array}{c}P_{s} \\
\left(\mathrm{~mL} \mathrm{H}_{2} / \mathrm{L}\right)\end{array}$ & $\begin{array}{l}\text { Hydrogen yield }(\mathrm{HY}) \\
\left(\mathrm{mol} \mathrm{H}_{2} / \text { mol glucose) }\right.\end{array}$ & $\begin{array}{c}\text { SHPR } \\
\left(\mathrm{mL} \mathrm{H}_{2} / \mathrm{g}-\mathrm{VSS} \mathrm{h}\right)\end{array}$ \\
\hline Optimum & 25.76 & 5.56 & 0.81 & 5489 & 1.83 & 77.31 \\
\hline High & 30 & 6 & 1 & 4172 & 1.30 & 58.73 \\
\hline Worst & 20 & 4 & 0.6 & 3442 & 1.71 & 48.45 \\
\hline Endo $^{\text {a }}$ & 20 & 5.56 & - & 2014 & 1.08 & 28.35 \\
\hline Control $^{\mathrm{b}}$ & 20 & 5.56 & - & 1874 & 1.04 & 26.37 \\
\hline
\end{tabular}

Notes: ${ }^{\text {a }}$ Pineapple waste extract contained $0.5 \mathrm{~mL} / \mathrm{L}$ Endo-nutrient; ${ }^{\mathrm{b}}$ Pineapple waste extract.

The biogas produced at the optimum conditions contained hydrogen (28\%) and carbon dioxide (72\%). No methane gas was detected. The time course of production of $P_{s}$ and SHPR obtained at the optimum conditions is depicted in Figure 3a. As shown in Figure 3a, after $4 \mathrm{~h}$ of lag phase, the $P_{s}$ and SHPR increased greatly. During fermentation time, $P_{s}$ increased over time and remained constant at the maximum level of $5427 \mathrm{~mL} \mathrm{H}_{2} / \mathrm{L}$. SHPR increased and reached a maximum level of $76.43 \mathrm{~mL}$ $\mathrm{H}_{2} / \mathrm{g}$-VSS $\mathrm{h}$ then decreased after $30 \mathrm{~h}$ (Figure $3 \mathrm{a}$ ). Figure $3 \mathrm{~b}$ illustrates the formation of VFAs and alcohols accompanying the production of hydrogen obtained at the optimum conditions. After a lag phase, the concentrations of VFAs and alcohols sharply increased. The fermentation products were butyric acid, acetic acid, ethanol and propionic acid. The detection of butyric and acetic acids was a good indicator that efficient hydrogen production had been achieved [25] and that the fermentation type was butyrate-acetate type fermentation.

The confirmation results in the treatment with Endo-nutrient addition and control (Table 5) confirmed the results attained from the Placktett-Burman (Table 1) that the Endo-nutrient does not have an individual effect on hydrogen production from pineapple waste extract by anaerobic mixed cultures. 
Figure 3. (a) $P_{s}$ and SHPR in the confirmation experiment at optimum condition; and (b) development of soluble metabolite products at the optimum condition.

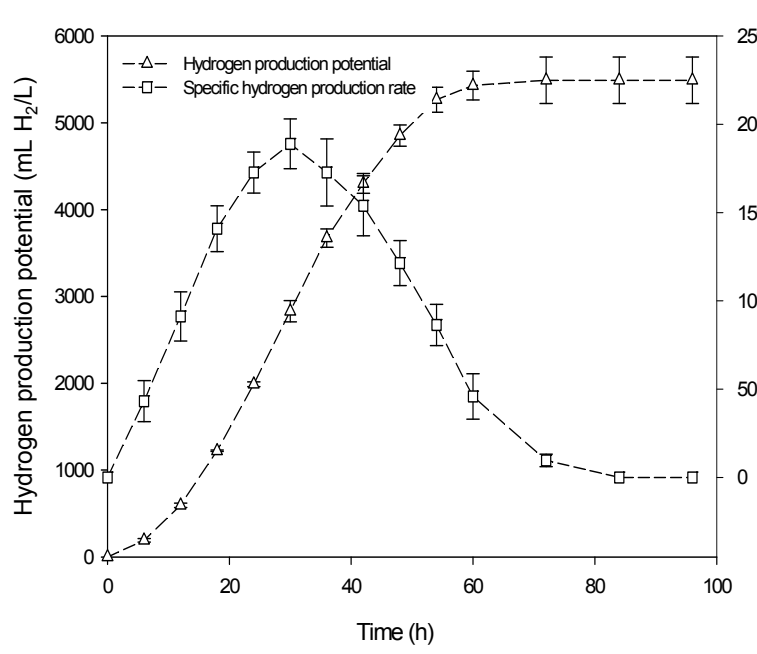

(a)
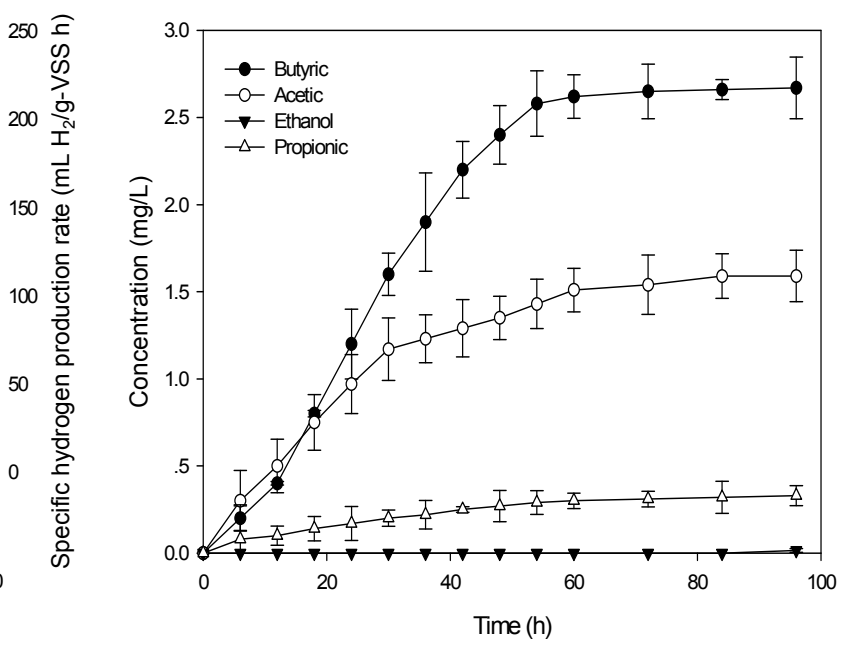

(b)

The maximum hydrogen yield (HY) $\left(1.82 \mathrm{~mol} \mathrm{H}_{2} / \mathrm{mol}\right.$ glucose $)$ obtained in this study was favorable compared with other results reported in the literature search (Table 6). However, the $P_{s}$ and HY of Saraphirom and Reungsang [26] were 1.26 and 1.21 times than ours, respectively, while the HY of Pan et al. [27] was 1.27 times higher than our HY. This is not surprising since the types/sources of inoculums and substrates used to produce hydrogen in their studies were different to those in our study. In addition, the $P_{s}, \mathrm{HY}$, and SHPR obtained from optimum conditions were approximately 2.93, 1.75, and 2.93, respectively, times higher than control (i.e., $20 \mathrm{~g} / \mathrm{L}$ pineapple waste extract without an addition of ferrous iron and Endo-nutrient) indicating a significant enhancement of $P_{s}, \mathrm{HY}$, and SHPR by adding ferrous iron.

Table 6. Comparison of $P_{s}$ and $\mathrm{HY}$ at the optimum conditions with various inoculums and substrates in the experimental batch.

\begin{tabular}{|c|c|c|c|c|c|}
\hline Inoculums & Substrate & Optimum conditions & 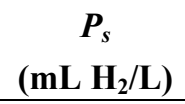 & $\begin{array}{c}\mathrm{HY} \\
\text { (mol H} / \text { mol glucose) }\end{array}$ & References \\
\hline Anaerobic sludge & glucose & $\begin{array}{l}26.80 \mathrm{~g} / \mathrm{L} \text { glucose, } \\
\text { pH } 7.0 \text { and } 39.3^{\circ} \mathrm{C}\end{array}$ & 3999 & 1.24 & {$[28]$} \\
\hline Anaerobic sludge & glucose & $\begin{array}{l}9.70 \mathrm{~g} / \mathrm{L} \text { glucose, } \\
\text { pH } 5.7 \text { and } 38^{\circ} \mathrm{C}\end{array}$ & - & 1.75 & [29] \\
\hline Clostridium sp. Fanp2 & glucose & $\begin{array}{c}23.75 \mathrm{~g} / \mathrm{L} \text { glucose } \\
0.159 \mathrm{M} \text { phosphate buffer and } \\
13.3 \mathrm{~mL} / \mathrm{L} \text { vitamine solution }\end{array}$ & 4166 & 2.33 & [27] \\
\hline Heat-treated sludge & glucose & $\begin{array}{l}9.70 \mathrm{~g} / \mathrm{L} \text { glucose, } \\
\text { pH } 5.5 \text { and } 41^{\circ} \mathrm{C}\end{array}$ & 2935 & 1.67 & {$[30]$} \\
\hline Heat-treated sludge & $\begin{array}{c}\text { Sweet } \\
\text { sorghum syrup }\end{array}$ & $\begin{array}{c}25 \mathrm{~g} / \mathrm{L} \text { glucose, } \mathrm{pH} 4.78 \\
\text { and } 1.45 \mathrm{~g} / \mathrm{L} \mathrm{FeSO}_{4}\end{array}$ & 6897 & 2.22 & {$[26]$} \\
\hline Heat-treated sludge & $\begin{array}{c}\text { Pineapple } \\
\text { waste extract }\end{array}$ & $\begin{array}{c}25.76 \mathrm{~g} / \mathrm{L} \text { glucose, } \mathrm{pH} 5.56 \\
0.81 \mathrm{~g} / \mathrm{L} \mathrm{FeSO}_{4} \text { and } 35^{\circ} \mathrm{C}\end{array}$ & 5489 & 1.83 & This study \\
\hline
\end{tabular}




\section{Experimental Section}

\subsection{Preparation of Feedstock}

Pineapple waste (residual peel and core waste) was obtained from fruit shops at Khon Kaen University, Khon Kaen, Thailand. The pineapple waste was chopped into small pieces using knives before being crushed in a blender. The crushed pineapple waste was squeezed by a presser to extract the juice before being filtered through a thin cloth and then concentrated by heating. The sugar concentration of the pineapple extract was 351 g-total sugar/L. Total nitrogen and total phosphorus of the extract were 0.50 and $0.30 \mathrm{~g} / \mathrm{L}$, respectively. The initial $\mathrm{pH}$ of the extract was 4.10 . The extract was kept in the freezer at $-20{ }^{\circ} \mathrm{C}$ until used. It was thawed in a refrigerator at $4{ }^{\circ} \mathrm{C}$ and centrifuged at $6000 \mathrm{rpm}$ for $10 \mathrm{~min}$ to separate the solids prior to being used to produce hydrogen.

\subsection{Inoculums Preparation}

Anaerobic seed sludge was obtained from a full-scale anaerobic digester of the upflow anaerobic sludge blanket (UASB) reactor of a brewery company, Khon Kaen, Thailand. The UASB is used to produce methane from the wastewater of the beer production process. The anaerobic seed sludge was pre-heated at $105{ }^{\circ} \mathrm{C}$ for $3 \mathrm{~h}$ in a drying oven (LDO-100E, Daihan Labtech Co., Ltd., Namyangju, Korea) in order to deactivate hydrogen consumers. The $\mathrm{pH}$ level and biomass concentration in terms of VSS of the sludge were 6.8 and $7.4 \mathrm{~g}-\mathrm{VSS} / \mathrm{L}$, respectively. In order to prepare the inocula, pre-heated sludge was cultivated in 20 g-total sugar/L of pineapple waste extract and supplemented with $0.5 \mathrm{~mL} / \mathrm{L}$ of Endo-nutrient solution [31]. The culture was incubated in a water bath shaker at $150 \mathrm{rpm}$ for $36 \mathrm{~h}$, before being used as the inocula in the batch experiment.

\subsection{Optimization Procedure}

\subsubsection{Placket-Burman Design}

A Placket-Burman design was used to screen the significant variables that influence the production of hydrogen from pineapple waste extract by anaerobic mixed cultures. The investigated experimental parameters were substrate concentration, initial $\mathrm{pH}, \mathrm{FeSO}_{4}$ concentration, Endo-nutrient addition, and $\mathrm{NaHCO}_{3}$ concentration. The experimental design [32] was based on the first-order model:

$$
Y_{i}=\beta_{0}+\sum \beta_{i} X_{i}
$$

where $Y_{i}$ are the responses i.e., $P_{s}$ and SHPR, $\beta_{0}$ is the model intercept; $\beta_{i}$ is the linear coefficient; and $X_{i}$ is the level of the independent variable. Each of variables was examined in two levels: -1 for low level and +1 for high level. The factors significant at the $95 \%$ level $(p \leq 0.05)$ were considered to have a significant effect on hydrogen production and were then used in the optimization step. The level of each factor and experimental design matrix used in the experimental design are shown in Tables 1 and 7. The effect of each variable was determined by the following equation:

$$
E_{x i}=2\left(\sum M_{i+}-M_{i-}\right) / N
$$


where, $E x_{i}$ is the concentration effect of the tested variable, $M_{i^{+}}$and $M_{i^{-}}$are $P_{s}$ and SHPR from runs where the variable $\left(X_{i}\right)$ measured was present at high and low concentrations, respectively, and $N$ is the number of runs (13). In order to approach the area of the optimum level, the next experiment was carried out along the path of steepest ascent (Table 2). The direction of the maximum increase in $P_{s}$ and SHPR was yielded by the gradient of the regressed polynomial. The factors significant at the $95 \%$ level $(p \leq 0.05)$ were considered to have a significant effect on the response and were thus used for further optimization by the steepest ascent.

Table 7. Plackett-Burman design matrix for evaluating factors influencing $P_{s}$ and SHPR from pineapple waste extract by anaerobic mixed cultures.

\begin{tabular}{|c|c|c|c|c|c|c|c|c|c|c|c|c|c|c|}
\hline \multirow[t]{2}{*}{ Run } & \multicolumn{2}{|c|}{$\begin{array}{c}\mathrm{FeSO}_{4} \\
\text { concentration } \\
(\mathrm{g} / \mathrm{L}) \\
\end{array}$} & \multicolumn{2}{|c|}{ Initial pH } & \multicolumn{2}{|c|}{$\begin{array}{l}\text { Endo-nutrient } \\
\text { addition }(\mathrm{mL} / \mathrm{L})\end{array}$} & \multicolumn{2}{|c|}{$\begin{array}{c}\text { Substrate } \\
\text { concentration } \\
\text { (g-total sugar/L) }\end{array}$} & \multicolumn{2}{|c|}{$\begin{array}{c}\mathrm{NaHCO}_{3} \\
\text { concentration } \\
(\mathrm{g} / \mathrm{L}) \\
\end{array}$} & \multicolumn{2}{|c|}{$\begin{array}{c}P_{s} \\
\left(\mathrm{~mL} \mathrm{H} \mathrm{H}_{2} / \mathrm{L}\right)\end{array}$} & \multicolumn{2}{|c|}{ 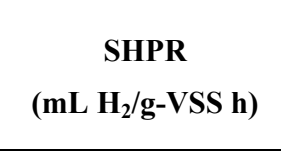 } \\
\hline & $\begin{array}{l}\text { Code } \\
\text { value }\end{array}$ & $\begin{array}{c}\text { Actual } \\
\text { value }\end{array}$ & $\begin{array}{l}\text { Code } \\
\text { value }\end{array}$ & $\begin{array}{l}\text { Actual } \\
\text { value }\end{array}$ & $\begin{array}{l}\text { Code } \\
\text { value }\end{array}$ & $\begin{array}{l}\text { Actual } \\
\text { value }\end{array}$ & $\begin{array}{l}\text { Code } \\
\text { value }\end{array}$ & $\begin{array}{l}\text { Actual } \\
\text { value }\end{array}$ & $\begin{array}{l}\text { Code } \\
\text { value }\end{array}$ & $\begin{array}{l}\text { Actual } \\
\text { value }\end{array}$ & Observed & Predicted & Observed & Predicted \\
\hline 1 & -1.00 & 1.00 & -1.00 & 5.00 & -1.00 & 0.50 & 1.00 & 20.00 & -1.00 & 1.00 & 3220 & 3250 & 45.33 & 44.42 \\
\hline 2 & -1.00 & 1.00 & -1.00 & 5.00 & 1.00 & 2.00 & -1.00 & 10.00 & 1.00 & 5.00 & 2656 & 2735 & 37.39 & 35.1 \\
\hline 3 & 1.00 & 2.00 & 1.00 & 7.00 & -1.00 & 0.50 & -1.00 & 10.00 & -1.00 & 1.00 & 1325 & 1091 & 18.65 & 19.92 \\
\hline 4 & 1.00 & 2.00 & -1.00 & 5.00 & -1.00 & 0.50 & -1.00 & 10.00 & 1.00 & 5.00 & 2399 & 2183 & 33.77 & 29.89 \\
\hline 5 & 0.00 & 1.50 & 0.00 & 4.50 & 0.00 & 1.75 & 0.00 & 15.00 & 0.00 & 4.50 & 2772 & 2123 & 39.02 & 39.83 \\
\hline 6 & -1.00 & 1.00 & 1.00 & 7.00 & 1.00 & 2.00 & 1.00 & 20.00 & -1.00 & 1.00 & 2207 & 2064 & 31.07 & 29.05 \\
\hline 7 & -1.00 & 1.00 & 1.00 & 7.00 & 1.00 & 2.00 & -1.00 & 10.00 & 1.00 & 5.00 & 1522 & 1545 & 21.43 & 21.75 \\
\hline 8 & -1.00 & 1.00 & -1.00 & 5.00 & -1.00 & 0.50 & -1.00 & 10.00 & -1.00 & 1.00 & 2623 & 2829 & 36.92 & 32.13 \\
\hline 9 & 1.00 & 2.00 & -1.00 & 5.00 & 1.00 & 2.00 & 1.00 & 20.00 & -1.00 & 1.00 & 2704 & 2704 & 38.07 & 36.66 \\
\hline 10 & 1.00 & 2.00 & 1.00 & 7.00 & -1.00 & 0.50 & 1.00 & 20.00 & 1.00 & 5.00 & 1008 & 1415 & 14.19 & 15.36 \\
\hline 11 & 1.00 & 2.00 & -1.00 & 5.00 & 1.00 & 2.00 & 1.00 & 20.00 & 1.00 & 5.00 & 2705 & 2607 & 38.08 & 38.46 \\
\hline 12 & 1.00 & 2.00 & 1.00 & 7.00 & 1.00 & 2.00 & -1.00 & 10.00 & -1.00 & 1.00 & 952 & 1093 & 13.4 & 14.03 \\
\hline 13 & -1.00 & 1.00 & 1.00 & 7.00 & -1.00 & 0.50 & 1.00 & 20.00 & 1.00 & 5.00 & 2159 & 1964 & 30.39 & 29.01 \\
\hline
\end{tabular}

\subsection{2. $\mathrm{CCD}$}

CCD was used to optimize the important factors that enhanced $P_{s}$ and SHPR. A total of 20 runs (Table 3), in triplicate, were conducted. The $P_{s}$ and SHPR were selected as the dependent output variables. For statistical calculations, the test factors $\left(X_{i}\right)$ were coded as $x_{i}$ according to the following transformation equation [Equation (5)]:

$$
x_{i}=\left(X_{i}-X_{0}\right) / \Delta X_{i}
$$

where $x_{i}$ is the coded value of the variable $X_{i} ; X_{i}$ is the actual value of the independent variable; $X_{0}$ is the actual value of $X_{i}$ at the center point and $X_{i}$ is the step change value. A quadratic model [Equation (6)] [33] was used to evaluate the optimization of the key factors:

$$
Y=\beta_{0}+\sum \beta_{i} X_{i}+\sum \beta_{i} X_{i}^{2}+\sum \beta_{i j} X_{i} X_{j}
$$

where $Y$ are the predicted responses ( $P_{s}$ and SHPR); $x_{i}$ is the parameter; $\beta_{0}$ is a constant; $\beta_{i}$ is the linear coefficient; $\beta_{i i}$ is the squared coefficient and $\beta_{i j}$ is the interaction coefficient. The response variables 
are $P_{s}$ and SHPR. These responses were fitted using a predictive polynomial quadratic Equation (6) in order to correlate the response variable with the independent variables [33]. $P_{s}$ was calculated by dividing the amount of hydrogen production $\left(\mathrm{mL} \mathrm{H}_{2}\right)$ by the working volume of the medium $(\mathrm{L})$. SHPR was calculated by dividing the hydrogen production rate $\left(\mathrm{mL} \mathrm{H}_{2} / \mathrm{h}\right)$ by the amount of biomass concentration in terms of VSS ( $\mathrm{g}$-VSS). HY ( $\mathrm{mol} \mathrm{H}_{2} / \mathrm{mol}$ hexose) was calculated by dividing the molar amount of hydrogen production $\left(\mathrm{mol} \mathrm{H}_{2} / \mathrm{L}\right)$ by the substrate consumption (mol hexose/L). The statistical software Design-Expert (Demo version 7.0, Stat-Ease, Inc., Minneapolis, MN, USA) was used for design, modeling and plotting the graphical analysis of the experimental data. The conditions of each trial are shown in Table 3.

\subsection{Biohydrogen Production}

The biohydrogen production experiment was conducted in $120 \mathrm{~mL}$ serum bottles with a working volume of $70 \mathrm{~mL}$. The fermentation broth contained different levels and concentrations of parameters, according to the design (Tables 2, 3, and 7). The serum bottles were capped with rubber stoppers and flushed with nitrogen gas in order to create anaerobic conditions. The bottles were incubated at $35{ }^{\circ} \mathrm{C}$, and $150 \mathrm{rpm}$ in a shaking water bath. At designated times the gas volume was measured by releasing the pressure in the bottles using a wetted glass syringe [34]. The effluent was collected by using a glass syringe and analyzed for VFAs and alcohol by gas chromatography (GC) equipped with a flame ionization detector (FID). The hydrogen production was continued until the biogas volume could not be measured.

\subsection{Analytical Methods}

The biogas compositions were measured by GC (GC-2014, Shimadzu, Kyoto, Japan) equipped with a thermal conductivity detector (TCD) and a $2 \mathrm{~m}$ stainless column packed with Unibeads C (60/80 mesh). The operational temperatures of the injection port, column oven and detector were set according to Saraphirom and Reungsang [26]. For the VFAs and alcohol analysis, the effluents were first centrifuged at $6000 \mathrm{rpm}$ for $10 \mathrm{~min}$, then acidified by $0.2 \mathrm{~mol} / \mathrm{L}$ oxalic acid, and finally filtered through a $0.45 \mathrm{~m}$ nylon membrane. The same GC model with a FID and a $30 \mathrm{~m} \times 0.25 \mathrm{~mm} \times 0.25 \mathrm{~m}$ capillary column (Stabilwax) was used to analyze the VFAs and alcohol concentrations. Operation conditions were set according to Saraphirom and Reungsang [26]. Total sugar was measured by phenol sulfuric method [35] using glucose as a standard. Total concentrations of nitrogen, phosphorus and VSS were measured according to the standard methods [36]. The hydrogen volume in the biogas was calculated by the mass balance equation [37]. Cumulative hydrogen production was calculated by the modified Gompertz equation [38].

\section{Conclusions}

The substrate concentration, initial $\mathrm{pH}$ and $\mathrm{FeSO}_{4}$ concentration were screened by a Plackett-Burman design as the key factors affecting the production of hydrogen from pineapple waste extract by anaerobic mixed cultures. These variables were optimized by the CCD in order to maximize the $P_{s}$ and SHPR. The optimum conditions attained were 25.76 g-total sugar/L, initial $\mathrm{pH}$ of 5.56 and $\mathrm{FeSO}_{4}$ 
concentration of $0.81 \mathrm{~g} / \mathrm{L}$. Under the optimum conditions, the estimated $P_{s}$ and SHPR were $5489 \mathrm{~mL} \mathrm{H}_{2} / \mathrm{L}$ and $77.31 \mathrm{~mL} \mathrm{H}_{2} / \mathrm{g}$-VSS h, respectively, which were close to the actual value of $5427 \mathrm{~mL} \mathrm{H} / \mathrm{L}$ and $76.43 \mathrm{~mL} \mathrm{H}_{2} / \mathrm{g}$-VSS h obtained from the confirmation experiment. The maximum $P_{s}$, HY, and SHPR obtained under the optimum conditions were 2.93, 1.75, and 2.93 times higher, respectively, than control. This suggests a significant enhancement of $P_{s}, \mathrm{HY}$, and SHPR by adding ferrous iron. However, it is important to note that the predicted data are suitable for batch fermentation of hydrogen only and does not necessarily mean that it can always apply to the continuous mode. The addition of Endo-nutrient does not enhance biohydrogen production from pineapple waste extract. The end products were predominantly butyrate and acetate, which generated a butyrate-acetate-type fermentation.

\section{Acknowledgments}

The authors appreciate the funding from Fermentation Research Center for Value-Added Agricultural Products, Khon Kaen University and National Research University Project through the Biofuels Research Cluster-Khon Kaen University, Office of the Higher Education Commission. Many thanks to Sureewan Sittijunda for the analytical support and technical assistance.

\section{References}

1. Benemann, J. Hydrogen biotechnology: Progress and prospects. Nat. Biotechnol. 1996, 14, 1101-1103.

2. Momirlan, M.; Veziroglu, T.N. Current status of hydrogen energy. Renew. Sustain. Energy Rev. 2002, 6, 141-179.

3. Chen, W.H.; Chen, S.Y.; Khanal, S.K.; Sung, S. Kinetic study of biological hydrogen production by anaerobic fermentation. Int. J. Hydrog. Energy 2006, 31, 2170-2178.

4. Correia, R.T.P.; Mccue, P.; Magalhaes, M.M.A.; Macedo, G.R.; Shetty, K. Production of phenolic antioxidants by the solid-state bioconversion of pineapple waste mixed with soy flour using Rhizopus oligosporus. Process Biochem. 2004, 39, 2167-2172.

5. Ruknongsang, P.; Reungsang, A.; Moonamart, S.; Danvirutai, P. Influence of nitrogen, acetate and propionate on hydrogen production from pineapple waste extract by Rhodospirillum rubrum. J. Water Environ. Technol. 2005, 3, 93-117.

6. Tanaka, K.; Hilary, Z.D.; Ishizaki, A. Investigation of the utility of pineapple juice and pineapple waste material as low-cost substrate for ethanol fermentation by Zymomonas mobilis. J. Biosci. Bioeng. 1999, 87, 642-646.

7. Nigam, J.N. Continuous ethanol production from pineapple cannery waste. J. Biotechnol. 1999, 72, 197-202.

8. Wang, C.H.; Lin, P.J.; Chang, J.S. Fermentative conversion of sucrose and pineapple waste into hydrogen gas in phosphate-buffered culture seeded with municipal sewage sludge. Process Biochem. 2006, 41, 1353-1358.

9. Lee, K.S.; Hsu, Y.F.; Lo, Y.C.; Lin, P.J.; Lin, C.Y.; Chang, J.S. Exploring optimal environmental factors for fermentative hydrogen production from starch using mixed anaerobic microflora. Int. J. Hydrog. Energy. 2008, 33, 1565-1572. 
10. Antonopoulou, G.; Gavala, H.N.; Skiadas, I.V.; Lyberatos, G. Influence of pH on fermentative hydrogen production from sweet sorghum extract. Int. J. Hydrog. Energy 2010, 35, 1921-1928.

11. Li, Z.; Wang, H.; Tang, Z.; Wang, X.; Bai, J. Effects of pH value and substrate concentration on hydrogen production from the anaerobic fermentation of glucose. Int. J. Hydrog. Energy 2008, 33, 7413-7418.

12. Sreela-or, C.; Plangklang, P.; Imai, T.; Reungsang, A. Co-digestion of food waste and sludge for hydrogen production by anaerobic mixed cultures: Statistical key factors optimization. Int. J. Hydrog. Energy 2011, 36, 14227-14237.

13. Van Ginkel, S.; Sung, S.W.; Lay, J.J. Biohydrogen production as a function of $\mathrm{pH}$ and substrate concentration. Environ. Sci. Technol. 2001, 35, 4726-4730.

14. Fan, Y.T.; Li, C.L.; Lay, J.J.; Hou, H.W.; Zhang, G.S. Optimization of initial substrate and pH levels for germination of sporing hydrogen-producing anaerobes in cow dung compost. Bioresour. Technol. 2004, 91, 189-193.

15. Khanal, S.K.; Chen, W.H.; Sung, S. Biological hydrogen production: Effects of pH and intermediate products. Int. J. Hydrog. Energy. 2004, 29, 1123-1131.

16. Dabrock, B.; Bahl, H.; Gottschalk, G. Parameters affecting solvent production by Clostridium acetobutyricum. Appl. Environ.1992, 58, 1233-1239.

17. Zhu, Y.; Yang, S.T. Effect of $\mathrm{pH}$ on metabolic pathway shift in fermentation of xylose by Clostridium tyrobutyricum. J. Biotechnol. 2004, 110, 143-157.

18. Zhang, T.; Liu, H.; Fang, H.H.P. Biohydrogen production from starch in wastewater under thermophilic conditions. J. Environ. Manag. 2003, 69, 149-156.

19. Wang, J.; Wan, W. Factor influencing fermentation hydrogen production: A review. Int. J. Hydrog. Energy 2009, 34, 759-811.

20. Frey, M. Hydrogenases: Hydrogen-activating enzymes. Chem. Bio. Chem. 2002, 3, 153-160.

21. Wang, J.; Wan, W. Effect of $\mathrm{Fe}^{+2}$ concentrations on fermentative hydrogen production by mixed cultures. Int. J. Hydrog. Energy 2008, 33, 1215-1220.

22. Yang, H.J.; Shen, J.Q. Effect of ferrous iron concentration on anaerobic bio-hydrogen production from soluble starch. Int. J. Hydrog. Energy 2006, 31, 2137-2146.

23. Ding, J.; Ren, N.Q.; Liu, M.; Ding, L. Effect of $\mathrm{Fe}$ and $\mathrm{Fe}^{2+}$ on hydrogen production capacity with mixed culture. Environ. Sci. 2004, 25, 48-53.

24. Ferchichi, M.; Crabbe, E.; Hintz, W.; Gil, G.H.; Almadidy, A. Influence of culture parameters on biological hydrogen production by Clostridium saccharoperbutylacetonicum ATCC 27021. World J. Microbiol. Biotechnol. 2005, 21, 855-862.

25. Zhang, Y.; Liu, G.; Shen, J. Hydrogen production in batch culture of mixed bacteria with sucrose under different iron concentrations. Int. J. Hydrog. Energy 2005, 30, 855-860.

26. Saraphirom, P.; Reungsang, A. Optimization of biohydrogen production from sweet sorghum syrup using statistical methods. Int. J. Hydrog. Energy 2010, 35, 13435-1344.

27. Pan, J.; Zhang, R.Z.; Elmashad, H.M.; Sun, H.; Ying, Y. Effect of food to microorganism ratio on biohydrogen production from food waste via anaerobic fermentation. Int. J. Hydrog. Energy 2008, 33, 6968-6975. 
28. Pan, C.M.; Fan, Y.T.; Xing, Y.; Hou, H.W. Statistical optimization of process parameters on biohydrogen production from glucose by Clostridium sp. Fanp2. Bioresour. Technol. 2008, 99, 3146-3154.

29. Mu, Y.; Wang, G.; Yu, H.Q. Response surface methodological analysis on biohydrogen production by enriched anaerobic cultures. Enzyme Microb. Technol. 2006, 38, 905-913.

30. Ren, N.Q.; Chua, H.; Chan, S.Y.; Tsang, Y.F.; Wang, Y.J.; Sin, N. Assessing optimal fermentation type for bio-hydrogen production in continuous flow acidogenic reactors. Bioresour. Technol. 2007, 98, 1774-1780.

31. Lin, C.Y.; Lay, C.H. A nutrient formulation for fermentative hydrogen production using anaerobic sewage sludge microflora. Int. J. Hydrog. Energy 2005, 30, 285-292.

32. Plackett, R.L.; Burman, J.P. The design of optimum multi factorial experiments. Biometrika 1946, 33, 305-325.

33. Lay, J.J. Modeling and optimization of anaerobic digested sludge converting starch to hydrogen. Biotechnol. Bioeng. 2002, 68, 269-278.

34. Owen, W.F.; Stuckey, D.C.; Healy, J.B., Jr.; Young, L.Y.; McCarty, P.L. Bioassay for monitoring bioenvironmental methane potential and anaerobic toxicity. Water Res. 1979, 13, 485-493.

35. Dubois, M.; Gilles, K.A.; Hamilton, J.K.; Rebers, P.A.; Smith, F. Phenol sulfuric total sugar. Anal. Chem. 1956, 28, 350-356.

36. Standard Methods for the Examination of Water and Wastewater, 19th ed; American Public Health Association: Washington, DC, USA, 1998.

37. Zheng, X.J.; Yu, H.Q. Inhibitory effects of butyrate on biological hydrogen production with mixed anaerobic cultures. J. Environ. Manag. 2005, 74, 65-70.

38. Onodera, H.; Miyahara, T.; Noike, T. Infuence of Ammonia Concentration on Hydrogen Transformation of Sucrose. In Proceedings of the 7th IAWQ Asia-Pacific Regional Conference, Taipei, Taiwan, 12-18 October 1999.

(C) 2013 by the authors; licensee MDPI, Basel, Switzerland. This article is an open access article distributed under the terms and conditions of the Creative Commons Attribution license (http://creativecommons.org/licenses/by/3.0/). 